\title{
A fibrin-related line of research and theoretical possibilities for the use of fibrin glue as a temporary basal membrane in non-perforated corneal ulcers and in photorefractive keratectomy (PRK)-operated corneas
}

\author{
Linha de pesquisa em fibrina e possibilidades teóricas de seu uso como \\ membrana basal provisória em úlceras corneanas não perfuradas $e$ em \\ córneas operadas de ceratectomia fotorrefrativa (PRK)
}

José Américo Bonatti ${ }^{1}$

Samir Jacob Bechara ${ }^{2}$

Marcelo Wesley Lopes Dall'Col ${ }^{3}$

Fernando Betty Cresta ${ }^{4}$

PedroCarlos Carricondo ${ }^{5}$

Newton Kara-José ${ }^{6}$
Trabalho realizado na Disciplina de Oftalmologia da Faculdade de Medicina da Universidade de São Paulo USP - São Paulo (SP) - Brasil.

Doutor em Oftalmologia pela Faculdade de Medicina da Universidade de São Paulo - USP - São Paulo (SP) Brasil

Professor Livre Docente de Oftalmologia pela Faculdade de Medicina da USP - São Paulo (SP) - Brasil.

Médico Estagiário da Disciplina de Oftalmologia da

Faculdade de Medicina da USP - São Paulo (SP) - Brasil.

${ }^{4}$ Doutor em Oftalmologia pela Faculdade de Medicina da USP - São Paulo (SP) - Brasil.

Médico Assistente da Fundação pela Faculdade de Medicina da USP - São Paulo (SP) - Brasil.

Professor Titular de Oftalmologia da Faculdade de Medicina da USP - São Paulo (SP) - Brasil.

Endereço para correspondência: José Américo Bonatti. Rua Teodoro Sampaio, 744 - Conj. 105 - São

Paulo (SP) CEP 05406-000

E-mail: bonatti@uol.com.br

Recebido para publicação em 27.09.2006

Última versão recebida em 24.03.2007

Aprovação em 24.04.2007

\begin{tabular}{l} 
ABSTRACT \\
\hline Purpose: To report a specific line of research developed at the University \\
of São Paulo/Brazil on fibrin glue used for sealing corneal perforations \\
and the perspectives of use on non-perforated corneal ulcers and pho- \\
torefractive keratectomy-operated corneas. Methods: To describe fibrin \\
glue manufacture, development of a device to test the glued perforated \\
corneal area resistance, subsequent experimental investigations of the \\
use of the fibrin glue in corneal perforations, reporting its efficacy, \\
mechanical resistance experiments and histological study. Finally, the \\
medical literature basis is searched to propose studies on the use of fibrin \\
as a temporary basal membrane on non-perforated corneal surfaces like \\
non-infectious corneal ulcers and on post-photorefractive keratectomy \\
corneal surfaces. Results: The development of fibrin glue, the device for \\
resistance experiments, the efficacy, resistance and histological studies \\
on fibrin glue used for sealing corneal perforations are reported as well \\
as the scientific literature basis for the proposed studies on the use of fibrin \\
as a temporary basal membrane on non-perforated corneas like non- \\
perforated corneal ulcers and photorefractive keratectomy corneal sur- \\
faces. Conclusion: A specific line of research was reported on fibrin glue \\
to seal corneal perforations at the University of São Paulo/Brazil and the \\
theoretical perspectives for the use of fibrin in non-perforated corneal \\
ulcers and on photorefractive keratectomy-operated corneas in an attempt \\
to reduce corneal haze.
\end{tabular}

Keywords: Corneal ulcer; Fibrin tissue adhesive; Basement membrane; Cornea/surgery; Keratectomy, photorefractive, excimer laser

\section{INTRODUCTION}

Fibrin is a blood derivative that is formed by the reaction between several plasma components. When fibrin is used in the treatment of corneal perforation, it is followed by subsequent healing and epithelial growth coating the injured area. The mechanical removal of the applied fibrin plug is not necessary because the local inflammatory process promotes its absorp- 
tion. Once the fibrin plug seals the wound, it is subsequently replaced by collagen progressing to the healing process ${ }^{(1-5)}$.

The glue is essentially formed by mixing two solutions that results in the final dense fibrin glue. Fibrinogen, factor $\mathrm{XIII}$, different plasma proteins as well as thrombin solution and calcium chloride react when blended. The fibrinogen molecules are changed for thrombin into monomer fibrin. The monomer fibrin is modified by factor XIII and calcium chloride, transforming the monomer fibrin into polymeric fibrin that is the final dense fibrin glue ${ }^{(6)}$. When the fibrin glue is applied to a corneal perforation, it adheres to the exposed collagen from the adjacent stroma forming a reticulum. Fibroblasts penetrate into this fibrin reticulum and begin to produce and deposit collagen as part of the healing process. In addition, the fibrin from the plug acts as a temporary basal membrane allowing the corneal epithelium to grow onto its surface. Therefore, fibrin glue seal will turn into a healing plug covered with epithelium which will totally close off the intra- and extraocular spaces.

Fibrinolysis breaks down the fibrin plug that is replaced by a scar. An antifibrinolytic agent may be associated with the mixture forming the fibrin glue to slow down fibrin plug breakdown $^{(7)}$.

The fibrin glue used nowadays in ophthalmology contains an antifibrinolytic agent to attenuate fibrin breakdown. This attenuation allows the gradual replacement of the fibrin by a scar without any major local structural changes until healing is complete, therefore diminishing the risks of further perforation.

Fibrin may be obtained from human donors. Therefore, the commercially available fibrin is extensively tested for blood-borne diseases. It is also submitted to thermo-virus inactivation and has been approved by FDA in 1998 for clinical use. Alternatively, the fibrin may be obtained from the patient undergoing treatment, thus minimizing risks of infectious diseases and immune reactions.

The use of one-donor human fibrinogen to glue corneal slices in vitro has been reported ${ }^{(8)}$. Fibrin glue in experimental epikeratophakic buttons in rabbits has also been employed. These experimental outcomes confirmed the autologous fibrinogen glue potential for the treatment of corneal perforation in humans avoiding the hazards of infections diseases and adverse immune reactions.

There are several clinical and experimental literature reports showing a satisfactory outcome of fibrin glue in different surgical procedures. To name a few in rabbits: Penetrating partial keratoplasties ${ }^{(9-10)}$, conjunctiva-corneal adherence, and lamellar keroplasty ${ }^{(11)}$. In humans: in cataract surgery to seal the corneo-scleral surgical incision, in sclero-conjunctival adherence, in partial penetrating keratoplasty, in chorioretinal adherence after retinal detachment ${ }^{(12)}$, fastening of epikeratophakial lenses ${ }^{(13)}$ in corneal perforation ${ }^{(2)}$, as a fixation support to the scleral bed in conjunctival autograft after surgical removal of pterygium ${ }^{(14)}$.

Additionally, fibrin has been studied in the treatment of infected corneal ulcers ${ }^{(15)}$. A similar clinical outcome was demonstrated with the use of two different tobramycin trials on experimental Pseudomonas aeruginosa corneal ulcers in rabbits. The first was the use of hourly tobramycin eyedrops and the second trial was the single application of local tobramycin encased in multiple large liposomes inserted in a fibrin glue reticulum adhered to the infected cornea.

The Ophthalmology Clinic of the University of São Paulo Medical School was the pioneer in Brazil of the clinical use of fibrin glue with good results for the treatment of corneal perforation. Two subjects with corneal perforations were successfully treated with fibrin glue ${ }^{(5)}$. One of the subjects presented peripheral corneal perforation secondary to cornea atrophy due to a previous surgical procedure to correct congenital cataract. This subject had also been previously submitted to several corneo-scleral surgical procedures to treat glaucoma. The second patient presented an infected perforated central corneal ulcer and dystrophy of the corneal posterior face caused by application of silicone oil for retinal detachment treatment. Fibrin glue in association with local antibiotics largely facilitated the healing and closure of the corneal perforation in the latter case.

Commercial Brazilian fibrin glue for clinical use is not currently available in Brazil. Imported glue increases costs significantly, especially if large amounts are required in a research setting. The demand for fibrin glue in Brazil has led Bonatti et al. to develop fibrin glue and a related line of research on this theme at the University of São Paulo Medical School.

Besides this line of research on fibrin glue to seal corneal perforations developed at the University of São Paulo and the routine use of this glue on perforated corneas, the authors nowadays think the fibrin glue would also work well as a temporary basal membrane on non-perforated corneal surfaces like those non-infected trophic, exposure and autoimune corneal ulcers and on photorefractive keratectomy (PRK)-operated corneas. This thought was based on a literature report ${ }^{(2)}$ and on personal medical reports at the Ophthalmic Clinic of the University of São Paulo: initially the successful use by the first author of fibrin glue covered by therapeutic contact lens on a non-infected post-trauma ulcer occurring on a radial keratotomy incision without reepithelialization despite the use of therapeutic contact lens alone, and other later successful cases of use of fibrin glue and therapeutic contact lens on non-infected indolent corneal ulcers reported by another experient member of the Clinics.

\section{PURPOSE}

The purpose of this paper is to report a specific line of research developed at the University of São Paulo on fibrin glue used for sealing corneal perforations and its perspectives of use on non-perforated corneal ulcers and on PRKoperated corneas. 


\section{METHODS}

\section{Development of the fibrin glue}

The fibrin glue was developed specifically to be employed in the treatment of experimental corneal perforation ${ }^{(16)}$.

\section{Previous evaluation of the fibrin glue in experimental corneal perforations}

This particular fibrin glue developed at the University of São Paulo Medical School to seal corneal perforations was submitted to clinical and histological analysis to evaluate its efficacy in the treatment of experimental 3-mm-wide circular corneal perforations in $\operatorname{dog} \mathrm{s}^{(3)}$.

\section{Development of a device to generate and to measure intraocular pressure}

A device to generate, measure and record intraocular pressure was developed specifically to test fibrin-glued corneal perforations ${ }^{(17)}$ (as well as the resistance of the applied fibrin plug over time). This particular device was made of parts that are usually available at any general hospital, like infusion pump, display and personal computer.

\section{Resistance measures and histological analysis of fibrin-glued experimental 3-mm-diameter corneal perforations}

Further studies in dogs have determined the fibrin plug mechanical resistance to graded elevation of intraocular pressure $^{(18)}$. Resistance measures and histological analysis were performed during 28 follow-up days. Intraocular pressure was generated and progressively increased, measured and recorded employing a device developed at the University of São Paulo Medical School ${ }^{(17)}$. The intraocular pressure level determining the rupture of the fibrin glue seal in 3-mmdiameter corneal perforation in dogs was recorded.

\section{Perform a literature search to theoretically justify studies about the use of fibrin glue on non-perforated corneal ulcers and on PRK-operated corneas}

Medline Pubmed literature was searched on the theme fibrin, non-perforated corneal ulcers and PRK-operated corneas to support a theoretical proposal for the use of fibrin glue to be used on the above mentioned corneal surfaces.

\section{RESULTS}

1. Fibrin glue was developed for corneal perforations ${ }^{(16)}$. This specific fibrin glue was composed of two liquid components which blended to form the solid fibrin glue. Component 1: A lyophilized cryoprecipitate solution of redissolved human plasma containing an average fibrin concentration of $14.8 \mathrm{mg} / \mathrm{ml}$, factor XIII, plasma proteins, and $250 \mathrm{mg} / \mathrm{ml}$ of tranexamic acid (antifibrynolysis agent). Component 2: A redissolved lyophilized bovine thrombin at $1.5 \mathrm{mg} / \mathrm{ml}$, and $40 \mathrm{mMol} / \mathrm{ml}$ calcium chloride.

2. This glue was initially evaluated in experimental corneal perforations.

The histological analysis demonstrated that the perforated cornea sealed with fibrin glue developed a low-grade inflammatory reaction scar coated with epithelium at about four weeks after the surgery, isolating the intraocular space from the extraocular space ${ }^{(3)}$.

3. A device to generate, measure and record intraocular pressure was obtained to be used for testing the resistance of fibrin-glued corneal perforations ${ }^{(17)}$.

4. In the resistance experience ${ }^{(18)}$ the intraocular rupture pressure (p) expressed in $\mathrm{mmHg}$ increased progressively from the second hour through the tenth experiment day $(t)$. The following mathematical formula was obtained: $p=30.0217+$ $29.4467(\mathrm{p}<0.05)$. On the $14^{\text {th }}$ and $28^{\text {th }}$ postoperative followup days, all corneal preparations included in the study resisted a pressure level up to $480 \mathrm{mmHg}$.

Histological analysis demonstrated epithelial growth coating the fibrin plug on the third postoperative day and progressive replacement of the fibrin for fibroblasts and collagen up to the $28^{\text {th }} \mathrm{PO}$ day when the fibrin was found to be totally replaced by a scar tissue. The fibrin plug site sustaining the experimental increase in intraocular pressure showed histological changes ranging from only fibrin deposition to a fibrin-free scarring reaction over the 28 -day period.

5. The result of the literature search showed:

Plasminogen is present in the cornea and can be activated to plasmin by plasminogen activator normally contained in epithelial cells in vivo or detected in the epithelial defect zone in response to tissue injury ${ }^{(19)}$.

Plasmin degrades both fibrin and fibronectin at the corneal ulceration, thus initiating the events that can lead to frank stromal ulceration ${ }^{(20)}$.

Corneal ulceration can be correlated with the apparent conversion of latent to active plasminogen activator ${ }^{(21)}$.

Plasmin is also able to activate latent collagenase, and this system could initiate and perpetuate the collagen degradation of corneal ulceration ${ }^{(22)}$.

Fibrin was successfully used on preperforated corneal ulcers being degraded physiologically, providing a good support for corneal healing ${ }^{(2)}$.

Fibrin tissue-filler glue was used for persistent epithelial defects ${ }^{(23)}$.

Amniotic membrane transplantation is a viable option in the treatment of nonhealing corneal ulcers of various depth and ethiologies. Perforations up to $3 \mathrm{~mm}$ can be safely managed by fibrin glue and amniotic membrane transplantation ${ }^{(24-25)}$.

Fibrin glue can be used to prevent the epithelial ingrowth and seal the flap after the debridement of epithelial ingrowth, a complication that can occur in the laser in situ keratomileusis (LASIK) ${ }^{(26-27)}$.

In LASIK surgery the myofibroblast activation (scar) oc- 
curred postoperatively at the flap edge, where there was an epithelial basement membrane break ${ }^{(28)}$.

After corneal superficial keratectomy in rabbits fibrin and fibronectin deposited on the bare surface of the cornea and persisted until the epithelium migrated onto these substances closing the wound. Fibronectin and fibrin were deposited onto the bare surface within 8 hours after wounding and persisted under the migrating epithelium until migration was complete. Migration of cells is a complex process, requiring both adhesion and controlled detachment as the cells move. Fibrin and fibronectin are important, perhaps essential components of the substrate used by migrating epitheliall cells in $\operatorname{vivo}^{(29)}$.

Fibrin and fibronectin deposition occurs within hours after injury onto the bare stroma after photokeratectomy during corneal wound repair and persists for several days until reepithelialization is complete Reepithelialization occurs within days of the procedure through migration of adjacent epithelial cells over the substratum formed by fibronectin and fibrin, working as temporary basal membrane. Fibrin promotes cell attachment and spreading on itself in vitro; the fibrin deposition immediately after corneal injury precedes the deposition of more permanent matrix proteins involved in corneal wound repair like collagen IV and laminin ${ }^{(30)}$. Fibrin was successfully used in humans for sutureless lamellar keratoplasty associated with contact lens bandage resulting in clear grafts, confirming the experimental results in rabbits ${ }^{(31-32)}$.

The time elapsed to repair the corneal epithelium in PRK can influence the degree of corneal haze ${ }^{(33)}$.

\section{DISCUSSION}

The ideal for local therapeutic agent corneal perforation is supposed to ${ }^{(34)}$ :

a) possess an elevated sealing power;

b) block the corneolytic and collagenolytic systems (more notably the collagenase system);

c) possess antifungal and antibacterial power;

d) be transparent for the patient's vision and for the examining physician's biomicroscopy;

e) be well tolerated by the patient and allow the therapeutical use of contact lenses;

f) stimulate the collagen repair system without inducing neovascularization or an intense inflammatory reaction;

g) promote the development of an inert substance for the replacement of sections of cornea;

h) have low costs and wide availability.

Fibrin is the best available glue to date because it fully complies with criteria a, e, f, g, h and complies in part with criteria $b$ and $d$. Yet, despite the fact fibrin is not an antimicrobial agent, fibrin can be safely blended with an antimicrobial agent.

Both fibrin and cyanoacrylate glues promote favorable conditions for corneal perforation healing. However, the ap- plication of cyanoacrylate glue requires the use of hydrophilic contact lenses to reduce eyelid inflammation and to prevent the clinical necessity of glue removal because of the local toxic effects ${ }^{(35)}$. Therefore, fibrin glue is more physiological than cyanoacrylate glue because it is fully absorbed and replaced by a scar with minimal inflammatory reaction. In the case where the fibrin glue is obtained from the patient's plasma, the risks of adverse immune reactions and infectious disease are greatly minimized.

As part of this line of research, an inventive device to generate, measure and record intraocular pressure with great precision was made evident for the corneal perforation experiment. The device injects fluid into the eye measuring up to $480 \mathrm{mmHg}$. This is far above the physiological pressure level. The device is appropriate for future experiments involving eye perforation wound resistance to graded intraocular pressure.

The results show a clear increase of the pressure endured by the fibrin glue-treated cornea along the scarring process. Fibrin glue is more physiological than cyanoacrylate glue because it is replaced by collagen, causes less local inflammatory reaction, does not require removal and requires no contact lenses.

It is recommended that fibrin glue application should be performed by skilled professionals. Removal of glue excess should be performed with the help of a pair of scissors and forceps to keep the glued section stable, as the mechanical resistance is minimal soon after the procedure.

As a new therapeutic alternative, the fibrin glue should, in addition to a clinical efficacy analysis, have its costs and availability taken into account as well. The fibrin glue that is currently available in Brazil is produced abroad and is therefore expensive. It runs up to US\$200.00 for $2 \mathrm{ml}$ and this obviously limits its clinical use.

For that reason a fibrin glue was developed ${ }^{(16)}$ in collaboration with the Fundação Pró-Sangue Hemocentro de São Paulo and the Surgical Technique Department.

The Brazilian glue solidifies in 5.6 seconds; which is quite an acceptable time for the treatment of corneal perforation. However, this glue is not available for clinical use in humans at present. Glue manufacturing does not meet the required minimal standards of thermo-virus inactivation despite the fact that the plasma is obtained from subjects submitted to extensive serologic testing for blood-borne infectious diseases.

The fibrin glue manufactured by the authors is less expensive than the imported glue. Preliminary appraisal assessed costs at US\$ 65.00 for $2 \mathrm{ml}$. Serologic tests to rule out bloodborne diseases were responsible for most of the production costs. The cost for $2 \mathrm{ml}$ of fibrin glue decreases to US\$ 10.00 if it is obtained from the own patient's plasma cryoprecipitate. This makes it more available to subjects from lower socioeconomic stratum.

This entire line of research was made real with partnership of the University of São Paulo Medical School Ophthalmo- 
logy Clinic that developed the protocol, with the assistance of the Fundação Pró-Sangue Hemocentro de São Paulo which manufactured the fibrin glue for the experiment, and the collaboration of the Surgical Technique Department whose facilities made the experimental assays possible.

The authors' effort is to manufacture the fibrin glue on a commercial basis marketed by the Fundação Pró-Sangue Hemocentro de São Paulo at lower costs compatible with the Brazilian realities. This enterprise along with experimental studies and clinical use in humans would make the development of this fibrin glue complete.

The use of fibrin glue for non-perforated corneal ulcers can have two advantages, initially the fibrin working as a temporary basal membrane allowing the epithelium to migrate adequately on it and secondly the inhibition of the fibrinolysis by the plasmin inhibitor tranexamic acid present in the fibrin glue, a fact that could avoid the perpetuation of the corneal ulcer.

In the case of PRK, one could use autologous fibrin immediately after surgery on the operated area in an attempt to create both a smoother and more regular surface (working as a temporary basal membrane for the corneal epithelium to grow immediately after surgery intending to reduce the reepithelialization time) and a chemical/mechanical barrier to protect the corneal stroma from the entrance of myofibroblast activating factors coming from the tears and corneal epithelium, in both suppositions theoretically contributing to the reduction of postoperative haze. By using the autologous fibrin glue the possibility of transmission of blood-borne diseases is eliminated.

\section{CONCLUSIONS}

The development of a line of research on fibrin glue to seal corneal perforations at the University of São Paulo Brazil and the theoretical perspectives of the use of fibrin on nonperforated corneal ulcers and PRK operated corneas were reported.

\section{RESUMO}

Objetivo: Relatar uma linha de pesquisa desenvolvida no Brasil (Universidade de São Paulo) em cola de fibrina para tamponamento de perfuração corneana e a perspectiva de seu uso em úlceras corneanas não perfuradas e em córneas operadas de ceratectomia fotorrefrativa. Métodos: Relatar a fabricação da cola de fibrina, desenvolvimento de instrumentação para ensaio de resistência da área colada, estudo experimental da eficácia, da resistência e histológico e levantada a literatura médica para embasar proposta de estudo da cola de fibrina como membrana basal provisória sobre superfícies corneanas não perfuradas como úlceras corneanas tróficas e superfícies corneanas operadas de ceratectomia fotorrefrativa. Resultados: O desenvolvimento da cola de fibrina, do equipamento para seu ensaio de resistência, os estudos experimentais de eficácia, resistência e histológico da área corneana colada com fibrina são relatados. É mostrada a base na literatura científica para a proposição de estudos com o uso de fibrina como membrana basal provisória sobre superfícies corneanas não perfuradas como úlceras tróficas e superfícies corneanas pós-ceratectomia fotorrefrativa. Conclusão: Foi relatada uma linha de pesquisa em cola de fibrina para tamponamento de perfuração corneana no Brasil (Universidade de São Paulo) e suas perspectivas teóricas de uso em úlceras corneanas não perfuradas e sobre córneas operadas de ceratectomia fotorrefrativa com intenção de reduzir "haze".

Descritores: Ulcera da córnea; Adesivo tecidual de fibrina; Membrana basal; Córnea/cirurgia; Ceratectomia fotorrefrativa por excimer laser

\section{REFERENCES}

1. Liggett PE, Skolik DS, Horio B, Saito Y, Alfaro V, Mieler W. Human autologous serum for the treatment of full-thickness macular holes - a preliminary study. Ophthalmology. 1995;102(7):1071-6.

2. Lagoutte FM, Gauthier L, Comte PR. A fibrin sealant for perforated and perforated corneal ulcers. Br J Ophthalmol. 1989;73(9):757-61

3. Bonatti JA, Tolosa EMC, Matheus LCA, Leitão R, Suzuki H, Kara-José N. Cola de fibrina me perfuração de córnea experimental em cão. Arq Bras Oftalmol. 1995;58(1):88-92.

4. Bonatti JA, Suzuki H, Kara-José N. Tratamento da úlcera corneana perfurada: revisão da literatura. Arq Bras Oftalmol. 1997;60(1):60-6.

5. Bonatti JA, Suzuki H, Kara-José N. Adesivo de fibrina em úlcera corneana perfurada. Arq Bras Oftalmol. 1997;60(1):111.

6. Morandini W, Ortiz V. Adesivos biológicos em cirurgia. Acta Cir Bras 1992;7(2):80-5.

7. Buschmann W, Stemberger A, Blümel G, Leydhecker W. [Fibrin adhesion and postoperative anti-fibrinolytic care of conjunctival wounds]. Klin Monatsbl Augenheilkd. 1984;184(3):185-8. German.

8. Brittain GP, Rostron CK, Morton DB, Rees JE. The use of a biological adhesive of achieve sutureless epikeratophakia. Eye. 1989;3(Pt 1):56-63.

9. Katzin HM. Aqueous fibrin fixation of corneal transplants in the rabbit. Arch Ophthalmol. 1946,35:415-20.

10. Rosenthal AR, Egbert PR, Harbury C, Hopkins JL, Rubenstein E. Use of platelet-fibrinogen-thrombin mixture to seal experimental penetrating corneal wounds. Albercht Von Graefes Arch Klin Exp Ophthalmol. 1978;207(2):111-5.

11. Rosenthal AR, Harbury C, Egbert PR, Rubenstein E. Use of a plateletfibrinogen-thrombin mixture as corneal adhesive experiments with sutureless lamellar keratoplasty in the rabbit. Invest.Ophthalmol. 1975;14(11):872-5.

12. Tassman IS. Experimental studies with physiologic glue (autogenous plasma plus thrombin) for use in the eyes. Am J Ophthalmol. 1950;33(6):870-8.

13. Rostron CK, Brittain GP, Morton DB, Rees JE. Experimental epikeratophakia with biological adhesive. Arch Ophthalmol. 1988;106(8):1103-6.

14. Cohen RA, McDonald MB. Fixation of conjuntival autographs with an organic tissue adhesive. Arch Ophthalmol. 1993;111(9):1167-8.

15. Frucht-Perry J, Assil K, Ziegler E, Douglas H, Brown SI, Schanzlin DJ, et al. Fibrin-enmeshed tobramycin lipossomes: single application topical therapy of Pseudomonas keratitis. Cornea. 1992;11(5):393-7.

16. Bonatti JA, Stefano JT, Matheus LC, Oliveira GA, Suzuki H, Kara-José N. Desenvolvimento de adesivo tecidual fibrínico para uso experimental em perfurações corneanas. Arq Bras Oftalmol. 1995;58(5):354-6.

17. Bonatti JA, Suzuki H, Kara-José N, Matheus LC. Desenvolvimento de equipamento de geração e registro de pressão intra-ocular suportada por perfuração corneana colada com fibrina. Arq Bras Oftalmol. 1977;60(5):514-5.

18. Bonatti JA, Suzuki H, Kara-José N, Alves MR, Matheus LC, Zanotto A, et al. Resistência à pressão intra-ocular e aspectos histopatológicos em ferimentos perfurantes corneanos colados com fibrina- estudo experimental. Arq Bras Oftalmol. 1998;61(1):15-24.

19. Hayashi K, Berman M, Smith D, el-Ghatit A, Pease S, Kenyon KR. Patho- 
genesis of corneal epithelial defects: role of plasminogen activator. Curr Eye Res. 1991;10(5):381-98.

20. Berman M, Manseau E, Law M, Aiken D. Ulceration is correlated with degradation of fibrin and fibronectin at the corneal surface. Invest Ophthalmol Vis Sci. 1983;24(10):1358-66.

21. Wang HM, Berman M, Law M. Latent and active plasminogen activator in corneal ulceration. Invest Ophthalmol Vis Sci. 1985;26(4):511-24.

22. Berman M, Leary R, Gage J. Evidence for a role of the plasminogen activator-plasmin system in corneal ulceration. Invest Ophthalmol Vis Sci. 1980;19 (10):1204-21.

23. Sumich PM, Cook SD, Tole DM. Fibrin tissue-filler glue for persistent epithelial defects. Clin Experiment Ophthalmol. 2003;31(3):267-9.

24. Hick S, Demers PE, Brunette I, La C, Mabon M, Duchesne B. Amniotic membrane transplantation and fibrin glue in the management of corneal ulcers and perforations: a review of 33 cases. Cornea. 2005;24(4):369-77.

25. Uhlig CE, Busse $H$, Groppe $M$. Use of fibrin glue in fixation of amniotic membranes in sterile corneal ulceration. Am J Ophthalmol. 2006;142(1):189-91.

26. Yeh DL, Bushley DM, Kim T. Treatment of traumatic LASIK flap dislocation and epithelial ingrowth with fibrin glue. Am J Ophthalmol. 2006;141(5):960-2 .

27. Anderson NJ, Hardten DR. Fibrin glue for the prevention of epithelial ingrowth after laser in situ keratomileusis. J Cataract Refract Surg. 2003;29(7): 1425-9.

28. Chang SW, Ashraf FM, Azar DT. Wound healing patterns following perfo- ration sustained during laser in situ keratomileusis. J Formos Med Assoc. 2000;99(8):635-41.

29. Fujikawa, LS, Foster CS, Gipson IK, Colvin RB. Basement membrane components in healing rabbit corneal epithelial wounds: imunofluorescence and ultrastructural studies. J Cell Biol. 1984;98(1):128-38.

30. Drew AF, Schiman HL, Kombrinck KW, Bugge TH, Degen JL, Kaufman AH. Persistent corneal haze after excimer laser photokeratectomy in plasminogen deficient mice. Invest Ophthalmol Vis Sci. 2000;41(1):67-72.

31. Kaufman HE, Insler MS, Ibrahim-Elzembely HA, Kaufman SC. Human fibrin tissue adhesive for sutureless lamellar keratoplasty and scleral patch adhesion: a pilot study. Ophthalmology. 2003;110(11):2168-72.

32. Ibrahim-Elzembely HA, Kaufman SC, Kaufman HE. Human fibrin tissue glue for corneal lamellar adhesion in rabbits: a preliminary study. Cornea. 2003;22 (8):735-9.

33. Netto MV, Ambrosio R Jr, Chalita MR, Krueger RR, Wilson SE. [Corneal wound healing response following different modalities of refractive surgical procedures]. Arq Bras Oftalmol. 2005;68(1):140-9. Portuguese.

34. Wendler ME, Lichtenberg W, Falzoni WL, Falzoni R, Belfort R Jr. Adesivos teciduais no tratamento de perfuração corneana. Estudo comparativo em cobaias. Arq Bras Oftalmol. 1983;46(2):138-40.

35. Aronson SB, McMaster PR, Moore TE Jr, Coon MA. Toxicity of the cyanoacrylates. Arch Ophthalmol. 1970;84(3)342-9. 